\title{
Different sources of phosphorus fertilizers and soil amendments affected the phosphorus and cadmium content in soil, roots and seeds of maize (Zea mays L.)
}

\author{
P. C. U. Wanninayake, ${ }^{1, a}$, M. A. P. W. K. Malaviarachchi ${ }^{2, b}$, R. P. Hettiarachchi ${ }^{3, c}$, P. N. Yapa ${ }^{1, d, *}$ \\ ${ }^{I}$ Department of Biological Sciences, Faculty of Applied Sciences, Rajarata University of Sri Lanka, Mihintale (50300), Sri Lanka. \\ ${ }^{2}$ Field Crop Research and Development Institute, Mahailluppallama, Sri Lanka \\ ${ }^{3}$ Soils and Plant Nutrition Department, Rubber Research Institute of Sri Lanka, Dartonfield, Agalawatta, Sri Lanka \\ *Corresponding author
}

\begin{tabular}{l|l} 
A R T I C L E I N F O & A B S T R A C T \\
\hline Research Article & $\begin{array}{l}\text { Phosphorus (P) fertilizers contain cadmium (Cd) as a contaminant at levels varying from trace } \\
\text { amounts to high levels and therefore, can be a major source of Cd to agricultural systems. This study } \\
\text { was designed to assess the impact on application of Eppawala rock phosphate (ERP) and triple super } \\
\text { phosphate (TSP) as P fertilizers and different soil amendments on P and Cd uptake in maize (Zea } \\
\text { mays L.). The field trial was carried out at Field Crop Research and Development Institute at } \\
\text { Mahailluppallama, Sri Lanka. A randomized complete block design was employed with three } \\
\text { replicates as ERP and TSP separately applied with arbuscular mycorrhizal fungi (AMF) and three } \\
\text { types of amendments (biochar, compost and dolomite) and the control without adding P fertilizers. } \\
\text { Phosphorus content and Cd content of soil, maize roots and seeds were quantified. Results revealed } \\
\text { that available soil Cd and total accumulated root and seed Cd amounts were significantly higher in } \\
\text { Accepted : 01/02/2021 } \\
\text { TSP added treatments with and without amendments compared with ERP added soil. Considering } \\
\text { soil available P, root and seed P, there was no significant difference observed in different treatments } \\
\text { of TSP and ERP added treatments. A similar phenomenon was also observed in growth and yield } \\
\text { parameters with both fertilizers added and with the added amendments. There was no colonization } \\
\text { of AMF in maize roots in TSP applied soil while 25-60\% of colonization was recorded with ERP. } \\
\text { Synthetic fertilizer (TSP) must have inhibited the AMF colonization and thereby increasing the Cd } \\
\text { content in maize seeds. AMF colonization increased with comparatively low soil available P in ERP } \\
\text { added treatments. The results revealed that TSP could be effectively substituted by ERP as a source } \\
\text { of P for maize soils. The addition of AMF, compost and biochar further increased the effect. }\end{array}$ \\
$\begin{array}{l}\text { Keywords: } \\
\text { Phosphorus }\end{array}$ \\
$\begin{array}{l}\text { Triple Super Phosphate } \\
\text { Eppawala Rock Phosphate }\end{array}$
\end{tabular}

\section{Introduction}

Phosphorus $(\mathrm{P})$ has acquired a significant role in plant growth and metabolism. It involves many important processes in plants such as energy transfer and storage, respiration, photosynthesis and enzyme regulation (Schachtman et al., 1998; Malhotra et al., 2018). Also P is part of structural component of DNA, RNA and membranes (Holford, 1997; Smith et al., 2011). Therefore, deficiency of $\mathrm{P}$ directly leads to loss of agricultural productivity in the world (Hinsinger, 2001; Leghari et al., 2016). It implies the necessity of adding $P$ to agricultural field externally. As a result, about 30 million tons of $\mathrm{P}$ fertilizer is applied worldwide every year. Mainly $\mathrm{P}$ fertilizers that are applied to agricultural fields can be categorized as basic slag $\left(12-18 \% \quad \mathrm{P}_{2} \mathrm{O}_{5}\right)$, single super phosphate (17-20\% $\mathrm{P}_{2} \mathrm{O}_{5}$ ), rock phosphate (26-37\% $\left.\mathrm{P}_{2} \mathrm{O}_{5}\right)$, di-calcium phosphate $\left(35-52 \% \quad \mathrm{P}_{2} \mathrm{O}_{5}\right)$ and triple super phosphate (44-48\% $\mathrm{P}_{2} \mathrm{O}_{5}$ ) (Dissanayake and Chandrajith,
2009). However, higher percentage of $P$ (up to $80 \%$ ) is escaped by becoming immobile or unavailable to uptake by plants because of adsorption, precipitation, leaching and conversion to organic forms (López-Bucio et al., 2000; Saleque et al., 2004; Ayaga et al., 2006). Therefore, efficient management of $\mathrm{P}$ fertilizers in cropping fields is required.

However, there are many limitations in soil, which leads to phytoavailability of $\mathrm{P}$ from the fertilizers. Such factors can be categorized as plant factors as crop variety, root development and distribution, crop yield level and soil factors such as soil texture, aeration, compaction, soil moisture, soil $\mathrm{pH}$, organic matter content and interaction with other nutrients (Beauchemin and Simard, 1999). Fertilizer based factors such as water solubility, chemical and physical forms of P (Armstrong, 1999; Alkhader, 2015). The effect of soil microorganisms such as 
arbuscular mycorrhizal fungi (AMF) and $\mathrm{P}$ solubilizing bacteria can be categorized as the soil biological factors. Therefore, manipulation of these factors that can enhance efficiency of $\mathrm{P}$ uptake by plants is a currently important concern (Miyasaka and Habte, 2001). However, excessive regular application of synthetic inorganic fertilizer to agricultural fields leads many environmental and health hazardous situations (Singh et al., 2017). Specially, accumulation of harmful residues such as heavy metals from fertilizers is more prominent (Grant et al., 2004; Singh et al., 2017). Therefore, implementation of the methods to increase the efficiency of $\mathrm{P}$ acquisition and usage by plants and to substitute synthetic $\mathrm{P}$ fertilizers with minimum hazardous impurities such as heavy metals is one of the research priorities. Both advantages and limitations of triple super phosphate have been reported as well (Edward et al., 2000; Grant and Sheppard, 2008). However, there is limited data in scientific literature about the usage of Eppawala rock phosphate (ERP) for crops such as maize, which is in short time period in field. This ERP normally contain low level of heavy metals than TSP because ERP originate from bed- rock, which is closer to the igneous type (Dissanayake and Chandrajith, 2009). Although there are limitations in the usage of ERP as a source of $\mathrm{P}$ due to its lower solubility than TSP, there are opportunities to make use of ERP when it applies with some soil amendments.

Here, the clear idea of the study is to manipulate the factors that can effect to absorption of $\mathrm{P}$ and $\mathrm{Cd}$ from fertilizers. In this case, selected amendments namely biochar, compost, dolomite and AMF use to manipulate soil conditions physically, chemically and biologically leading to increase $\mathrm{P}$ phytoavailability and reduce absorption of $\mathrm{Cd}$ in to plant. The phenomenon about the usage of compost, it can reduce the phosphorus fixation in soils by creating a competition between organic acids and orthophosphate for adsorption sites resulting release of phosphorus by this organic material in the case of decomposition. Also combine application of compost with commercial inorganic fertilizers can increase the efficiency of inorganic fertilizer and reduce the cost for frequent addition of synthetic fertilizers (Kwabiah et al., 2003). The idea for the selection of biochar for the study is that biochar application have resulted a higher grain yields at sites with low $\mathrm{P}$ availability and improved the response to nitrogen and phosphorus chemical fertilizer treatments according to the literature (Jha et al., 2010). Biochar appear as multischeme player by improving soil physical properties (Herath et al., 2013), reducing soil fertility constraints (Mia et al., 2014) and stimulating soil biological processes (Wang et al., 2015) leading to enhance crop performance. As well as, Physical amelioration of lime or dolomite occurs through flocculation of colloid particles which leads to changes in surface potential and charge densities (Bolan et al., 2003). Accordingly, it reduces $\mathrm{P}$ sorption and increase the concentration of $\mathrm{HPO}_{4}{ }^{2-}$ in the soil solution (Straaten, 2007) leading to increase the amount of available P for plant uptake (Kisinyo, 2013). When consider the reason to AMF selection for the study, this AMF colonization directly provides the advantages to host plants through contributing the nutrient uptake process especially to phosphorus uptake even in low nutrient conditions in rhizosphere using its very large surface area that is involving efficient nutrient uptake from different regions and volumes of soil while rapidly delivered to cortical cells within the root (Zhu et al., 2001). Therefore, the aim of the study was to assess $\mathrm{P}$ and cadmium $(\mathrm{Cd})$ in soil, roots and seeds of maize (Zea mays L.) as affected by the application of ERP and TSP fertilizers with combine application of $\mathrm{AMF}$ and the other soil amendments such as biochar, compost and dolomite.

\section{Materials and Methods}

\section{Experimental Sites}

The field experiment was carried out at Field Crops Research and Development Institute, Mahailluppallama $\left(08.60^{\circ} \mathrm{N}, 80.27^{\circ} \mathrm{E}, 137 \mathrm{~m}\right.$ amsl), Sri Lanka, which is in Low country Dry Zone from January 2018 to June 2018. The annual average rainfall of this region is $900-1100 \mathrm{~mm}$. The soil at the experimental site is Rhodustalfs, with a moderately well-drained sandy clay loam texture (Panabokke, 1996). The initial pH of the soil was 6.7.

\section{Experimental Treatments and Design}

The experimental design was randomized complete block design with three replicates. The plot size was $2.4 \mathrm{~m}$ $\mathrm{x} 1.2 \mathrm{~m}$ spaced at $30 \mathrm{~cm}$ apart from each other. ERP and TSP were separately applied with AMF and three types of amendments namely biochar, compost and dolomite as different treatments, $\mathrm{T}_{1}$ - no any $\mathrm{P}$ addition, $\mathrm{T}_{2}$ - TSP alone $\left(100 \mathrm{~kg} \mathrm{ha}^{-1}\right), \mathrm{T}_{3}$ - ERP alone (153.3 $\left.\mathrm{kg} \mathrm{ha}^{-1}\right), \mathrm{T}_{4}-\mathrm{AMF}$ inoculants only $\left(4 \mathrm{t} \mathrm{ha}^{-1}\right), \mathrm{T}_{5}$ - TSP $\left(100 \mathrm{~kg} \mathrm{ha}^{-1}\right)+$ AMF , $\mathrm{T}_{6}-\operatorname{ERP}\left(153.3 \mathrm{~kg} \mathrm{ha}^{-1}\right)+\operatorname{AMF}\left(4 \mathrm{t} \mathrm{ha}^{-1}\right), \mathrm{T}_{7}-$ compost only $\left(8 \mathrm{tha}^{-1}\right), \mathrm{T}_{8}-\mathrm{TSP}\left(100 \mathrm{~kg} \mathrm{ha}^{-1}\right)+$ compost $\left(8 \mathrm{t} \mathrm{ha}^{-1}\right)$, $\mathrm{T}_{9}-\operatorname{ERP}\left(153.3 \mathrm{~kg} \mathrm{ha}^{-1}\right)+$ compost $\left(8 \mathrm{t} \mathrm{ha}^{-1}\right), \mathrm{T}_{10}$ - dolomite $\left(2 \mathrm{t} \mathrm{ha}^{-1}\right)$ only, $\mathrm{T}_{11^{-}}$TSP $\left(100 \mathrm{~kg} \mathrm{ha}^{-1}\right)+$ dolomite $\left(2 \mathrm{t} \mathrm{ha}^{-1}\right)$, $\mathrm{T}_{12}$ - ERP $\left(153.3 \mathrm{~kg} \mathrm{ha}^{-1}\right)+$ dolomite $\left(2 \mathrm{t} \mathrm{ha}^{-1}\right), \mathrm{T}_{13}$ - biochar (4 $\left.\mathrm{t} \mathrm{ha}^{-1}\right)$ only, $\mathrm{T}_{14}$ - TSP $\left(100 \mathrm{~kg} \mathrm{ha}^{-1}\right)+\operatorname{biochar}\left(4 \mathrm{t} \mathrm{ha}^{-1}\right)$, $\mathrm{T}_{15}$ - ERP $\left(153.3 \mathrm{~kg} \mathrm{ha}^{-1}\right)+\operatorname{biochar}\left(4 \mathrm{tha}^{-1}\right)$.

\section{Crop Establishment and Maintenance}

Maize (variety MIMZ HY01), was established by direct seeding after disc-plouhging and harrowing the experimental field. Plots were prepared with shallow drains around them. The crop was planted at an inter-row spacing of $60 \mathrm{~cm}$ and intra-row spacing of $30 \mathrm{~cm}$. Two seeds per hill were sown at the beginning and thinned out to have a plant density of $5.55 \mathrm{~m}^{-2}$. An equal amount of (3 $\mathrm{kg})$ common organic nutrition supplement mixture (1:1, powdered Gliricidia sp. leaves: cow dung) was incorporated to each plot and mixed with soil by racking before the establishment of the crop. Compost was prepared using house yard manures while biochar was prepared using partial hydrolysis of wood chips. AMF inoculants were prepared using trap culture method using maize plant as the host and initial colonization percentage was verified following McGonigle method (McGonigle et al., 1990). Then compost, dolomite, AMF inoculants (with $75 \%$ initial colonization percentage) and biochar were added to plots according to the treatment plan. Pests and diseases were controlled by periodic spraying of liquid prepared with using neem (Azadiractha indica) plant parts and by cultural practices. Plots were kept weed-free and all other cultivation practices were followed as recommended by the Department of Agriculture, Sri Lanka. 


\section{Measurements and Data Analysis}

\section{Growth and yield parameters}

Plant height, number of leaves per plant, total leaf area was measured at flowering and harvesting stages of maize plants taking randomly-selected plants per plot. A destructive sampling of randomly selected plants was used to measure the dry weight of roots, leaves and seeds at harvesting stage. Total grain yield with moisture percentage was measured in the net plot area and the moisture was adjusted to $14 \%$.

Cadmium analysis of soil, roots and seeds of maize

The maize was harvested and seeds were separated from the cob at 105 days after establishment. The remaining plants were uprooted and separated into roots, shoot and leaves. Roots were washed with tap water to remove all the soil particles. Thereafter, seed, leaf and root samples were oven dried at $65^{\circ} \mathrm{C}$. Soil samples collected from each plot separately was air dried for 2 days and sieved through the $2 \mathrm{~mm}$ mesh.

The digestion of sample was carried out using, $0.5 \mathrm{~g}$ of ground plant sample, $5 \mathrm{ml}$ of acid mixture $\left(\mathrm{HNO}_{3}: \mathrm{HClO}_{4}\right.$, $3: 2$ ) and acid digestion was carried out on block digester at $200{ }^{\circ} \mathrm{C}$ about 2 hours. Quantification of $\mathrm{Cd}$ was done using Atomic Absorption Spectrophotometer (GBC 902/903 AAS-Australia). The $\mathrm{Cd}$ in soil was also quantified following this procedure and $1 \mathrm{~g}$ of sieved soil was used.

Phosphorus analysis of soil, roots and seeds of maize

The Olsen method (Watanabe and Olsen, 1965) was followed to determine soil $\mathrm{P}$ content of the sample and ammonium vana-molybdate was used as coloring reagent. Quantification of $\mathrm{P}$ was done using Spectrophotometer (Model No. UV/1800 APC) at $882 \mathrm{~nm}$ wave length. Phosphorus content of plant samples were measured using dry-ashing method. Then samples were read for $\mathrm{P}$ using Spectrophotometer at $410 \mathrm{~nm}$ wave length.

Determination of final AMF colonization percentage in roots and $\mathrm{pH}$ of soil

Determination of AMF colonization percentage was done following the modified grid transects method (McGonigle et al., 1990) and soil pH was also estimated before and at the end of trial.

\section{Statistical Analysis}

Data were analyzed using Analysis of Variance in MINITAB version 16.2.1. Tukey's Method at $\mathrm{P}<0.05$ was used to test the differences among treatment means. All statistical analysis was performed using MINITAB version 16.2.1.

\section{Results}

Initial Cd level of added TSP was $1.00 \mathrm{ppm}$ and $\mathrm{Cd}$ level of ERP was below detection level. The statistical analysis of present study revealed that, the soil, maize root and seed $\mathrm{Cd}$ concentrations were significantly high $(\mathrm{P}<0.05)$ in TSP added treatments compared with the ERP added treatments. However, the soil Cd concentration of the other treatments with added AMF and the amendments with TSP was significantly lower than the treatment of only added TSP (Table 1). However, even with the addition of AMF, compost, biochar and dolomite has shown significantly high $(\mathrm{P}<0.05) \mathrm{Cd}$ concentrations in soil, maize roots and seeds of TSP added treatments compared to the ERP added treatments of respective amendments. Further it was shown that AMF with TSP treatment was shown significantly higher $\mathrm{Cd}$ level in soil, maize roots and seeds $(\mathrm{P}<0.05)$ and lower level of $\mathrm{Cd}$ was recorded in ERP with AMF (Table 1). This can be explained by considering the estimated percentage of colonization of AMF in plant roots. Although initial AMF colonization of maize root samples taken from the trap culture was approximately $75 \%$, there was no colonization observed in the maize roots harvested from soil of TSP added treatments. As well as, AMF colonization of maize roots in soil ERP added treatments was ranged between $25-60 \%$. This can be explained by the adverse impact of synthetic TSP on soil AMF propagules which lower the AMF colonization of roots. Further the study was shown that ERP with AMF has significantly contributed to lower the seed $\mathrm{Cd}$ level retaining higher $\mathrm{Cd}$ amounts in roots. Further, the study has also revealed that the compost and biochar with both TSP and ERP have obtained significantly lower mean $(\mathrm{P}<0.05)$ of $\mathrm{Cd}$ levels in soil, roots and seeds, independent from the type of tested $\mathrm{P}$ fertilizers.

Table 1. Mean Cd concentrations of soil, roots and seeds at the harvesting stage of maize (ppm). BDL - Below detection level

\begin{tabular}{l|ccc}
\hline \multicolumn{1}{c|}{ Treatments } & $\begin{array}{c}\text { Cd concentration in soil } \\
(\mathrm{ppm})\end{array}$ & $\begin{array}{c}\text { Cd concentration in roots } \\
(\mathrm{ppm})\end{array}$ & $\begin{array}{c}\text { Cd concentration in seeds } \\
(\mathrm{ppm})\end{array}$ \\
\hline no any P addition & $\mathrm{BDL}$ & $\mathrm{BDL}$ & $\mathrm{BDL}$ \\
TSP alone & 0.12 & 0.09 & 0.05 \\
ERP alone & 0.08 & 0.05 & 0.03 \\
AMF inoculants only & $\mathrm{BDL}$ & $\mathrm{BDL}$ & $\mathrm{BDL}$ \\
TSP+ AMF & 0.09 & 0.06 & 0.06 \\
ERP+ AMF & 0.03 & 0.05 & 0.01 \\
compost only & $\mathrm{BDL}$ & $\mathrm{BDL}$ & $\mathrm{BDL}$ \\
TSP + compost & 0.05 & 0.02 & 0.02 \\
ERP +compost & 0.01 & 0.01 & $\mathrm{BDL}$ \\
Dolomite only & $\mathrm{BDL}$ & $\mathrm{BDL}$ & $\mathrm{BDL}$ \\
TSP +dolomite & 0.08 & 0.05 & 0.02 \\
ERP +dolomite & 0.07 & 0.02 & 0.02 \\
Biochar only & $\mathrm{BDL}$ & $\mathrm{BDL}$ & $\mathrm{BDL}$ \\
TSP +biochar & 0.04 & 0.02 & 0.02 \\
ERP +biochar & 0.02 & 0.01 & BDL \\
\hline
\end{tabular}


Table 2. Mean P concentrations of soil, roots and seeds at the harvesting stage of maize (ppm)

\begin{tabular}{l|ccc}
\hline \multicolumn{1}{c|}{ Treatments } & $\begin{array}{c}\text { Concentration in soil } \\
(\mathrm{ppm})\end{array}$ & $\begin{array}{c}\text { Concentration in roots } \\
(\mathrm{ppm})\end{array}$ & $\begin{array}{c}\text { Concentration in seeds } \\
(\mathrm{ppm})\end{array}$ \\
\hline No any P addition & 12.20 & 83.83 & 160.21 \\
TSP alone & 21.59 & 189.52 & 239.04 \\
ERP alone & 17.94 & 139.56 & 237.90 \\
AMF inoculants only & 23.09 & 94.33 & 236.95 \\
TSP+ AMF & 21.95 & 125.36 & 238.76 \\
ERP+ AMF & 18.03 & 136.14 & 233.09 \\
compost only & 23.16 & 171.83 & 225.61 \\
TSP + compost & 37.46 & 161.16 & 237.62 \\
ERP + compost & 23.88 & 198.86 & 239.14 \\
Dolomite only & 20.59 & 165.68 & 171.17 \\
TSP + dolomite & 26.81 & 120.17 & 236.33 \\
ERP +dolomite & 22.81 & 219.74 & 182.61 \\
Biochar only & 20.30 & 208.54 & 235.04 \\
TSP + biochar & 32.38 & 179.56 & 238.09 \\
ERP +biochar & 20.52 & 190.85 & 238.31 \\
\hline
\end{tabular}

Table 3. Growth and yield parameters of maize plants. Means that do not share a same letter are significantly different $(\mathrm{P}<0.05)$.

\begin{tabular}{|c|c|c|c|c|c|c|}
\hline \multirow{2}{*}{ Treatment No. } & \multicolumn{3}{|c|}{$\begin{array}{c}\text { Growth parameters of maize plants for different } \\
\text { treatment (Mean) }\end{array}$} & \multicolumn{3}{|c|}{ Dry biomass of plant parts (Mean) } \\
\hline & $\begin{array}{l}\text { Height of plant } \\
(\mathrm{cm})\end{array}$ & No of leaves & $\begin{array}{l}\text { Leaf area } \\
\left(\mathrm{cm}^{2}\right)\end{array}$ & $\begin{array}{c}\text { Seeds } \\
\left(\mathrm{g} \text { plant }^{-1}\right)\end{array}$ & $\begin{array}{l}\text { Roots } \\
(\mathrm{g})\end{array}$ & $\begin{array}{l}\text { Leaves } \\
\quad(g)\end{array}$ \\
\hline $\mathrm{T}_{1}$ & $31.2^{\mathrm{a}}$ & $10^{\mathrm{a}}$ & $226.7^{a}$ & $94.5^{\mathrm{a}}$ & $4.2^{\mathrm{a}}$ & $41.8^{\mathrm{a}}$ \\
\hline $\mathrm{T}_{2}$ & $59.3^{\mathrm{b}}$ & $11^{\mathrm{a}}$ & $518.9^{\mathrm{b}}$ & $97.2^{\mathrm{a}}$ & $6.0^{\mathrm{a}}$ & $73.2^{\mathrm{b}}$ \\
\hline $\mathrm{T}_{3}$ & $61.3^{\mathrm{b}}$ & $11^{\mathrm{a}}$ & $520.4^{\mathrm{b}}$ & $91.6^{\mathrm{a}}$ & $5.3^{\mathrm{a}}$ & $60.9^{\mathrm{b}}$ \\
\hline $\mathrm{T}_{4}$ & $54.2^{\mathrm{b}}$ & $11^{\mathrm{a}}$ & $442.3^{b}$ & $90.4^{\mathrm{a}}$ & $5.4^{\mathrm{a}}$ & $68.8^{\mathrm{b}}$ \\
\hline $\mathrm{T}_{5}$ & $53.0^{\mathrm{b}}$ & $11^{\mathrm{a}}$ & $490.6^{\mathrm{b}}$ & $88.0^{\mathrm{a}}$ & $5.7^{\mathrm{a}}$ & $73.6^{b}$ \\
\hline $\mathrm{T}_{6}$ & $63.9^{\mathrm{b}}$ & $11^{\mathrm{a}}$ & $518.3^{\mathrm{b}}$ & $95.2^{\mathrm{a}}$ & $4.5^{\mathrm{a}}$ & $68.8^{\mathrm{b}}$ \\
\hline $\mathrm{T}_{7}$ & $61.4^{\mathrm{b}}$ & $10^{\mathrm{a}}$ & $473.9^{\mathrm{b}}$ & $94.4^{\mathrm{a}}$ & $6.6^{\mathrm{a}}$ & $80.9^{b}$ \\
\hline $\mathrm{T}_{8}$ & $72.8^{\mathrm{b}}$ & $11^{\mathrm{a}}$ & $555.8^{\mathrm{b}}$ & $96.8^{\mathrm{a}}$ & $4.8^{\mathrm{a}}$ & $78.2^{\mathrm{b}}$ \\
\hline $\mathrm{T}_{9}$ & $71.0^{\mathrm{b}}$ & $11^{\mathrm{a}}$ & $504.3^{\mathrm{b}}$ & $94.0^{\mathrm{a}}$ & $6.0^{\mathrm{a}}$ & $68.9^{\mathrm{b}}$ \\
\hline $\mathrm{T}_{10}$ & $60.2^{\mathrm{b}}$ & $11^{\mathrm{a}}$ & $471.2^{\mathrm{b}}$ & $96.4^{\mathrm{a}}$ & $5.3^{\mathrm{a}}$ & $72.7^{b}$ \\
\hline $\mathrm{T}_{11}$ & $61.7^{\mathrm{b}}$ & $11^{\mathrm{a}}$ & $537.8^{\mathrm{b}}$ & $94.0^{\mathrm{a}}$ & $5.4^{\mathrm{a}}$ & $77.1^{\mathrm{b}}$ \\
\hline $\mathrm{T}_{12}$ & $67.6^{\mathrm{b}}$ & $10^{\mathrm{a}}$ & $522.1^{\mathrm{b}}$ & $87.6^{\mathrm{a}}$ & $8.2^{\mathrm{a}}$ & $76.5^{\mathrm{b}}$ \\
\hline $\mathrm{T}_{13}$ & $62.5^{\mathrm{b}}$ & $10^{\mathrm{a}}$ & $400.9^{\mathrm{b}}$ & $91.2^{\mathrm{a}}$ & $3.1^{\mathrm{a}}$ & $60.5^{\mathrm{b}}$ \\
\hline $\mathrm{T}_{14}$ & $65.9^{\mathrm{b}}$ & $10^{\mathrm{a}}$ & $512.9^{b}$ & $95.2^{\mathrm{a}}$ & $5.7^{\mathrm{a}}$ & $68.5^{b}$ \\
\hline $\mathrm{T}_{15}$ & $78.6^{\mathrm{b}}$ & $12^{\mathrm{a}}$ & $575.4^{\mathrm{b}}$ & $98.4^{\mathrm{a}}$ & $8.1^{\mathrm{a}}$ & $71.5^{\mathrm{b}}$ \\
\hline
\end{tabular}

[T $T_{1}-$ no any $\mathrm{P}$ addition, $\mathrm{T}_{2}-$ TSP alone, $\mathrm{T}_{3}-\mathrm{ERP}$ alone, $\mathrm{T}_{4}-$ AMF inoculants only, $\mathrm{T}_{5}-\mathrm{TSP}+$ AMF inoculants, $\mathrm{T}_{6}-\mathrm{ERP}+\mathrm{AMF}$ inoculants, $\mathrm{T}_{7}-$ compost only, $\mathrm{T}_{8}-\mathrm{TSP}+$ compost, $\mathrm{T}_{9}-\mathrm{ERP}+$ compost, $\mathrm{T}_{10}-$ Dolomite only, $\mathrm{T}_{11}-\mathrm{TSP}+$ dolomite, $\mathrm{T}_{12}-\mathrm{ERP}+\mathrm{dolomite}, \mathrm{T}_{13}-\mathrm{Bioch}$ ar only, $\mathrm{T}_{14}-$ TSP+biochar, $\mathrm{T}_{15}-\mathrm{ERP}+$ biochar]

The dolomite added with fertilizers was not recorded considerable performance to manipulate $\mathrm{Cd}$ level when compared with other amendments.

When consider the $\mathrm{P}$ analysis, it was revealed that there was no significant difference $(\mathrm{P}>0.05)$ between TSP added treatments and ERP added treatment for soil $\mathrm{P}$ concentration. However, mean soil P content was higher in compost added plots with TSP and ERP fertilizers. Also mean higher soil content next to compost amendment was shown in biochar added treatment with both ERP and TSP fertilizers. It was observed in the present study also, there were no considerable effect for soil $\mathrm{P}$ was recorded TSP and ERP with AMF.

Considering growth and yield parameters it was revealed that there was a significant difference $(\mathrm{P}<0.05)$ between control (without addition of any P fertilizers) and the other treatments (Table 3) and there was no significant difference $(\mathrm{P}>0.05)$ between any other treatments. Considering height, leaf area and dry mass of roots, biochar added treatment with ERP has acquired higher means than the others. Soil $\mathrm{pH}$ values of all control and experimental plots were reached 7.2 - 7.9 range and initial $\mathrm{pH}$ was 6.7 in the field. At the harvesting period there was no significant difference $(\mathrm{P}>0.05)$ between any treatments. But compost added treatments have shown higher $\mathrm{pH}$ of 7.9. Considering biochar added treatments with fertilizers in to soil, the $\mathrm{pH}$ has reached 7.8.

\section{Discussion}

Soil application of triple super phosphate increases the available soil $\mathrm{Cd}$ than the application of Eppawala rock phosphate (Wijewardhana, 1998). Further the TSP contributes to increase of accumulated $\mathrm{Cd}$ in maize root and seeds compared with ERP. Therefore, an application of sparingly soluble ERP as soil $\mathrm{P}$ fertilizer reduces available soil $\mathrm{Cd}$ and it is important in having a healthy soil. Considering $\mathrm{Cd}$ accumulation of roots and edible seeds, application of ERP increases safe consumption of maize. ERP with AMF significantly contribute to lower the seed $\mathrm{Cd}$ level retaining higher $\mathrm{Cd}$ amounts in roots because AMF can minimize the translocation of heavy metal (HM) 
from roots to shoot by compartmentalization HM in roots (Jiang et al., 2016). Biochar and compost are effective soil amendments for maize cultivation with the ameliorating effect of soil $\mathrm{Cd}$ absorption. When consider the compost and biochar, both these amendments have high binding capacity for cationic and organic contaminants which might lead to immobilization of heavy metals (Planquart et al., 1999; Murray et al., 2011). Also compost addition play another important role by enhancing soil organic matter content and their further decomposition released organic acids and $\mathrm{CO}_{2}$ gas leading to reduce $\mathrm{pH}$ while raising $\mathrm{P}$ availability and decrease $P$ fixation by soil (Kulasinghe et al., 2013). Compost might possess specific ability to adsorb the organic anions and the corresponding release of hydroxyl ions (Hue, 1992), may be the reason of slight increase of $\mathrm{pH}$. Because of such ameliorating properties of compost can be effectively used in maize cultivation in slightly acidic soil. As well as, biochar addition increase soil $\mathrm{P}$ because, application of biochar to soil can dissolve phosphates bounds to free cations such as $\mathrm{Ca}^{2+}, \mathrm{Mg}^{2+}, \mathrm{Fe}^{3+}$ and $\mathrm{Al}^{3+}$ leading to release $\mathrm{P}$ for plant uptake (Zhang et al., 2016).In the case of $\mathrm{pH}$ manipulation by biochar, it starts to release cations in to the soil solution and these cations displace exchangeable acidity and contribute to neutralize soil $\mathrm{pH}$ and furthermore, the biochar with higher ash alkalinity has a stronger ability to adjust soil acidity (Gaskin et al., 2008; Keith et al., 2011).

Although many scientific researchers have proved that colonization of AMF contribute to raise $\mathrm{P}$ bioavailability leading to increase the growth and yield of maize plants (Higo et al., 2018), some other studies were shown that available soil $\mathrm{P}$ content has inversely affect the colonization level of AMF (Xu et al., 2014). According to $\mathrm{Xu}$ et al., (2014), host plants tend to increase their restriction to AMF colonization when plant has abundant soluble $\mathrm{P}$ for their usage. Therefore, soil application of TSP adversely affects soil AMF and also the potential of root colonization. Further, addition of ERP to soil reduces the potential of root AMF colonization, because of the available $\mathrm{P}$ in soil. AMF colonized maize roots are compartmentalized the $\mathrm{Cd}$ in roots of maize and hence reduce the accumulation of seed cadmium. Dolomite/lime need significantly long time period to manipulate soil $\mathrm{pH}$ to effect ion exchange process (Watt, 1991). Considering soil $\mathrm{P}$ availability and $\mathrm{Cd}$ accumulation in edible seeds of maize, TSP can be effectively substitute by ERP for maize crop P requirement and sustainable maize crop cultivation. Further, ERP addition with AMF, compost and biochar further enhance the effect.

\section{References}

AlkhaderAMF. 2015.The impact of phosphorus fertilizers on heavy metals content of soils and vegetables grown on selected farms in Jordan. Agrotechnol., 5:137. DOI: 10.4172/2168-9881.1000137

Armstrong DL. 1999. Functions of phosphorus in plants.D.L. Armstrong (Ed.), Better crops with plant food., Potash \& Phosphate Institute (1999), pp. 6-7.

Ayaga G, Todd A, Brookes PC. 2006. Enhanced biological cycling of phosphorus increases its availability to crops in low input sub-saharan farming systems. Soil Biol. Biochem. 38:81-90. DOI:10.1016/j.soilbio.2005.04.019
Beauchemin S, Simard RR. 1999. Soil phosphorus saturation degree: review of some indices and their suitability for $\mathrm{P}$ management in Quebec, Canada. Can. J. Soil Sci., 79: 615625.DOI: $10.4141 / \mathrm{s} 98-087$

Bolan NS, Adriano DC, Curtin D. 2003. Soil acidification and liming interactions with nutrient and heavy metal transformation and bioavailability. Advances in Agronomy. 78:215-272.

Dissanayake CB, Chandrajith R. 2009. Phosphate mineral fertilizers, trace metals and human health - A review. J. Nat. Sci. Found., 37:153-165. DOI: 10.4038/jnsfsr.v37i3.1219

Edwards R, Dixon DP, Walbot V. 2000. Plant glutathione Stransferase enzyme with multiple function in sickness and health. University of Durham. Gen. Biol., 5: 193198.DOI:10.1016/s1360-1385(00)01601-0

Gaskin JW, Steiner C, Harris K, Das KC, Bibens B. 2008. Effect of low-temperature pyrolysis conditions on biochar for agricultural use. Trans ASABE,51: 2061-2069.DOI: 10.13031/2013.25409

Grant CA, Bittman S, Montreal M, Plenchette C, Morel M. 2004. Soil and fertilizer phosphorus: Effects on plant P supply and mycorrhizal development. Can J Plant Sci.,24: 163-171. DOI: org/10.4141/CJPS10136.

Grant CA, Sheppard SC.2008. Fertilizer impact on Cd availability in agricultural soils and crops. Human and ecological risk assessment: Int J Biol.,14: 210-228.DOI:org/10.1080/ 10807030801934895

Herath, H.M.S.K., Camps-Arbestain, M., Hedley, M. (2013). Effect of biochar on soil physical properties in two contrasting soils: An Alfisol and an Andisol. Geoderma. 209210, 188-197.

Higo M, Takahashi Y, Gunji K, Isobe K. 2018. How are AM associations related to maize growth performance during short-term cover crop rotation? J Sci of Food Agric.,98: 13881396.DOI: org/10.1002/jsfa.8606.

HinsingerP.2001. Bioavailability of soil inorganic $P$ in the rhizosphere as affectedby root-induced chemical changes: a review. Plant Soil, 237: 173-195.DOI: 10.1023/A: 1013351617532

Holford JCR. 1997. Soil Phosphorus; its measurement and uptake by plants. Aust J Soil Res., 35: 227-239.Available from: http://www.publish.csiro.au/?paper=S96047 [21.12.2018].

Hue NV.1992. Correcting soil acidity of a highly weathered Ultisol with chicken manure and sewage sludge. Commun Soil Sci Plant., 23: 241-264.Jiang Q, Zhuo F, Long S, Zhao H, Yang D, Ye Z, Li S, Jing X. 2016. Can AMF reduce Cd uptake and alleviate $\mathrm{Cd}$ toxicity of Lonicera japonica grown in Cd-added soil. Sci Reports,21: 201-217.DOI: 10.1038/srep21805.

Jha, P., Biswas, A.K., Lakaria, B.L. and Rao, A.S. (2010). Biochar in agriculture - prospects and related implications-A review. Current Science. 99(10):1218-1225.

Keith A, Singh B, Singh BH. 2011. Interacting priming of biochar and labile organic matter mineralization in a smectite-rich soil. Environ Sci. Technol., 45: 9611-9618.DOI: 10.1021/es202186j.

Kisinyo PO, Othieno CO, Gudu SO, Okalebo JR, Opala PA, Maghanga JK, Ngetich WK, Agalo JJ, Opile RW, Kisinyo JA, Ogola BO. 2013. Phosphorus sorption and lime requirements of maize growing acid soils of Kenya. Sustainable Agricultural Research. 2(2): 116-123.

Kulasinghe KPN, Wijebandara DMDI, Nugawela A, Fernandopulle MND. 2013. Performance of Eppawala rock phosphate with organic manure as a Phosphate source for adult coconut palms in dry zone (DL3). Agricultural Research Symposium, Coconut Research Institute of Lunuwilla,Sri Lanka, pp.180-184. 
Kwabiah AB, Stoskopf NC, Palm CA, Voroney RP, Rao MR, Gacheru E. 2003. Phosphorus availability and maize response to organic and inorganic fertilizer inputs in a short term study in western Kenya. Agric Ecosyst Environ . 95: 49-59.

Leghari SJ, Buriro M, Jogi Q, Kandhro MN, Leghari AJ.2016. Depletion of Phosphorus reserves, a big threat to agriculture: challenges and opportunities.Sci.Int.(Lahore).,28(3):26972710.Available from:https://www.researchgate.net/publication/ 304937113.[10.12.2018].

López-Bucio J, Lavega OM, Guevara-García A, Herrera-Estrella L. 2000. Enhanced phosphorus uptake in transgenic tobacco plants that overproduce citrate. Nat Biotechnol., 18: 450-453. DOI: $10.1038 / 74531$.

Malhotra H, Vandana, Sharma S, Pandey R. 2018. Phosphorus Nutrition: Plant Growth in Response to Deficiency and Excess. Plant Nutrients and Abiotic Stress Tolerance.pp.171180. DOI: 10.1007/978-981-10-9044-8_7.

McGonigle TP, Miller MH, Evans DG, Feirchild GL, Swan JA.1990. A new method which gives an objective measure of colonization of roots by vesicular-arbuscularmycorrhizal fungi. New Phytol.,115:495-501. Available from: https://doi.org/10.1111/j.1469-8137.1990.tb00476.x. [25.12.2018].

Mia S, van Groenigen JW, van de Voorde TFJ, Oram NJ, Bezemer TM, Mommer L, Jeffery S. 2014. Biochar application rate affects biological nitrogen fixation in red clover conditional on potassium availability. Agric Ecosyst Environ. 191: 83-91.

Miyasaka S, Habte M.2001. Plant mechanisms and mycorrhizal symbioses to increase phosphorus uptake efficiency. Commun Soil Sci Plant.,32(7):1101-1147. DOI: 10.1081/ CSS-100104105

Murray, Hollydawn, Trevor A, Sheila M. 2011. Compost application affect metal uptake in plants grown in urban garden soil and potential human health risk. J.Soil. Sediments,11(5):820-825. Available from: http://dx.doi.org/ 10.1007/s11368-011-0359-y.[10.02.2019].

Panabokke CR. 1996. Soils and agro-ecological environments of Sri Lanka. Colombo, Sri Lanka: NARESA. xvi, 220p. (Natural resources series no.2) Planquart P, Bonin G, Prone A, Massiani C. 1999. Distribution, movement and plant availability of trace metals in soil amended with sewage sludge composts. Sci Total Environ., 241: 161-179. Available from: https://doi.org/10.3232/SJSS.2017.V7.N1.03. [10.02.2019].

Saleque MA, Naher UA, Islam A, Pathan ABMBU, Hossain ATMS, Meisner CA. 2004. Inorganic and organic phosphorus fertilizer effects on the phosphorus fraction in wetland rice soils. Soil Sci. Soc of Am J., 68: 1635-1644. DOI: 10.2136/sssaj2004.1635.
Schachtman DP, Reid RJ, Ayling SM. 1998. Phosphorus uptake by plants; from soil to cell. Plant Physiol., 116: 447453.DOI:10.1104/pp.116.2.447.

Singh BR, Dependra KC, Åsgeir RA. 2017. Long-term effect of phosphate fertilization on cadmium uptake by oat and its accumulation in soil. J Environ Anal Toxicol., 7: 516. DOI: 10.4172/2161-0525.1000516.

Smith SE, Jacobsen I, Gronland M, Smith FA.2011. Roles of arbuscularmycorrhizas in plant phosphorus nutrition: interactions between pathways of $\mathrm{P}$ uptake in AM roots have important implications. Plant Physiol., 111: 174581. DOI:10.1104/pp.111.174581

Straaten PV. 2007. Agro geology: the use of rocks for crops.pp.440. Enviroquest ltd, Cambridge, Ontario.

Veneklaas EJ, Lambers H, Bragg J, Finnegan PM, Lovelock CE, Plaxton WC, Schachtman DP, Reid RJ, Ayling SM. 2012. Phosphorus uptake by plants: from soil to cell. Plant Physiol.,116:447-453.DOI:10.3389/fpls.2019.00405.

Wang C, Anderson C, Suárez-Abelenda M, Wang T, CampsArbestain M, Ahmad R, Herath HMSK. 2015. The chemical composition of native organic matter influences the response of bacterial community to input of biochar and fresh plant material. Plant Soil. 1-18.

Watanabe FA, Olsen JR. 1965. The use of polyacrylamide in the determination of Olsen's extractable phosphate in soil. J Soil Sci.,27: 71-74.

Watt HVH. 1991. Amelioration of subsoil acidity by application of a coal derived calcium fulvate to the soil surface. Nature,350: 146-148. DOI:10.1038/350146a0.

Wijewardena, JDH. 1998. Effects of phosphorus sources and levels with particular emphasis of selectively mined Eppawala Rock Phosphate on vegetable production. Journal of the National Science Foundation of Sri Lanka, 26(2): 93100. DOI: http://doi.org/10.4038/jnsfsr.v26i2.3558Xu P, Liang LZ, Dong XY, Xu J, Jiang PK, Shen RF.2014. Response of soil $\mathrm{P}$ required for maximum growth of Asparagus officinalis L. to inoculation of AMF. Pedoshere, 24: 776-782. Available from:https://doi.org/10.1016/S10020160(14)60064-3.[10.12.2018].

Zhu YG, Cavagnaro TR, Smith SE, Dickson S. 2001. Backseat driving, accessing phosphate beyond the rhizosphere depletion zone. Trends in Plant Science. 6:194-195,

Zhang H, Chen C, Gray EM, Boyd SE, Yang H, Zhang D.2016. Roles of biochar in improving $\mathrm{P}$ availability in soils: A phosphate adsorbent and a source of available phosphorus. Geoderma, 276:1-6. Available from:https://doi.org/ 10.1016.[10.12.2018]. 